\title{
Emeishan Basalts, SW China: reappraisal of the formation's type area stratigraphy and a discussion of its significance as a large igneous province
}

\author{
GARY M. THOMPSON ${ }^{1,4}$, JASON R. ALI ${ }^{1}$, XIEYAN SONG ${ }^{1,2} \&$ DAVID W. JOLLEY ${ }^{3}$ \\ ${ }^{1}$ Department of Earth Sciences, University of Hong Kong, Pokfulam Road, Hong Kong, P.R. China \\ (e-mail:jrali@hku.hk) \\ ${ }^{4}$ Present address: Beppu Geothermal Institute, Kyoto University, Noguchibaru, Beppu, Oita, 874-0903, Japan \\ ${ }^{2}$ Chengdu University of Technology, Chengdu, Sichuan, P.R. China \\ ${ }^{3}$ Environmental and Geological Sciences, University of Sheffield, Dainton Building, Brookhill, Sheffield, S3 7HF, UK
}

\begin{abstract}
The late Permian Emcishan Basalt Formation of SW China is one of Earth's LIPs flarge igneous provinces), yet its basic geology remains poorly documented. Recent work on sections close to the type area in Sichuan Province enable us in part to rectify this. Deseriptions of the formation and associated units at two areas, one on the lower flanks of Mt Emei and another from a series of outcrops in Ebian County, $50.70 \mathrm{~km}$ to the $\mathrm{SW}$, are presented. The basalt pile is $180-270 \mathrm{~m}$ thick and in both areas comprises 12 flows that were erupted in relatively quick succession. It rests conformably upon shallowmarine limestones/lignites suggesting emplacement close to sea level. The upper half of the youngest basalt was intensively weathered, but not eroded, prior to it being conformably succeeded by complex body of rocks $c .30 \mathrm{~m}$ thick. that includes thin basalts, pyroclastic rocks, tuffs and organic-rich terrestrial sediments. This unit, which has previously been described as a sedimentary package, presumably because intense weathering has obscured the primary lithological fabric in key outcrops, is considered to mark the volcanic waning phase. Uppermost Permian and Triassic terrestrial sediments conformably overlie the terminal volcanic rocks. The sub-regional stratigraphy is compared, as best it can be, with that described from two sections $400 \mathrm{~km}$ to the $\mathrm{SE}$; one section matches reasonably well, the other does not, indicating that regional correlations need to be developed carefully. The information is discussed in the context of LIP generator models; several key features of the Emeishan Basalt terrain are at odds with those commonly encountered in LIP's. The most important conclusion is that the unit marks a prematurely terminated system in which full bloodied rifting leading to the development of an ocean basin never started.
\end{abstract}

Keywords: Permian, South China Block, flood basalts, mantle plumes, rifting.

Over the past three decades, large igneous provinces (LIPs) have featured prominently in the geological literature. Such terrains are characterized by massive volumes of primarily basaltic lava (typically $0.5-2 \times 10^{6} \mathrm{~km}^{3}$ ) that were erupted onto Earth's surface within 1-3 million years, and are key elements in discussions on mantle plumes, rifted continental margins and global biotic crises (e.g. Storey et al. 1992: Mahoney \& Coffin 1997; Courtillot er al. 1999; Courtillot 1999). One group of models proposed for LIP generation has focused on large deep mantle plumes impacting the base of the lithosphere. Of these, one sub-group involves the ascending plume head 'punching' up into the lithosphere, followed almost immediately by magma production and eruption (Richards et al. 1989; Campbell \& Griffiths 1990). A second sub-group involves the plume head more slowly 'cooking' the lithosphere followed sometime later by lithospheric thinning-extension and largescale decompression volcanism (White \& McKenzie 1989; Kent et al. 1992). A key aspect of the plume model variants is that they argue for considerable crustal uplift above the plume head, for example the White McKenzie model has $1-2 \mathrm{~km}$ uplift above the plume head with a doming occurring over an area $2000 \mathrm{~km}$ in diameter. However, it must be noted that several workers (e.g. Mutter et al. 1988; Anderson et al. 1992; King \& Anderson 1995; Sheth 1999; Keen \& Boutilier 2000) have proposed LIP generator models that are controlled entirely by processes within the astheno-lithosphere with no involvement of a mantle plume. From the opinions and data presented at the 2000 Penrose Conference on Volcanic Rifted Margins (Menzies et al. 2000), it is now clear that several models, not necessarily exclusive, can reasonably explain the nature of emplacement of the recognized LIPs from across the globe. Thus, to understand the basics of LIP formation requires a full appreciation of each province to identify the elements that are both common and unique.

The Emeishan Basalt Formation of SW China (Fig. 1) is one of the terrains mentioned in LIP discussions (e.g. Courtillot et al. 1999), specifically in the context of continental rupture and its more evolved form the volcanic rifted margin. Compared to the other LIPs it is small, $0.25-0.5 \times 10^{6} \mathrm{~km}^{3}$ being the respective estimates of Huang \& Opdyke (1998) and Wang et al. (1987). However, its close temporal relationship to both the massive Siberian LIP $\left(3 \times 10^{6} \mathrm{~km}^{3}\right)$ and the major extinction marked by the Permian-Triassic boundary, for which a volcanism-related link is based on sections in SE China (e.g. Jin et al. 2000), suggests that it could have played an important role as the Palaeozoic Earth system terminated. Although the Emeishan Basalts have been described extensively in the Chinese literature, discussion of the unit in terms of the plume/non-plume LIP models has been limited (e.g. Chung \& Jahn 1995; Chung et al. 1998; the paper by Courtillot et al. 1999 reviews the Emeishan LIP using mainly the work of Chung and colleagues). Although those studies presented 


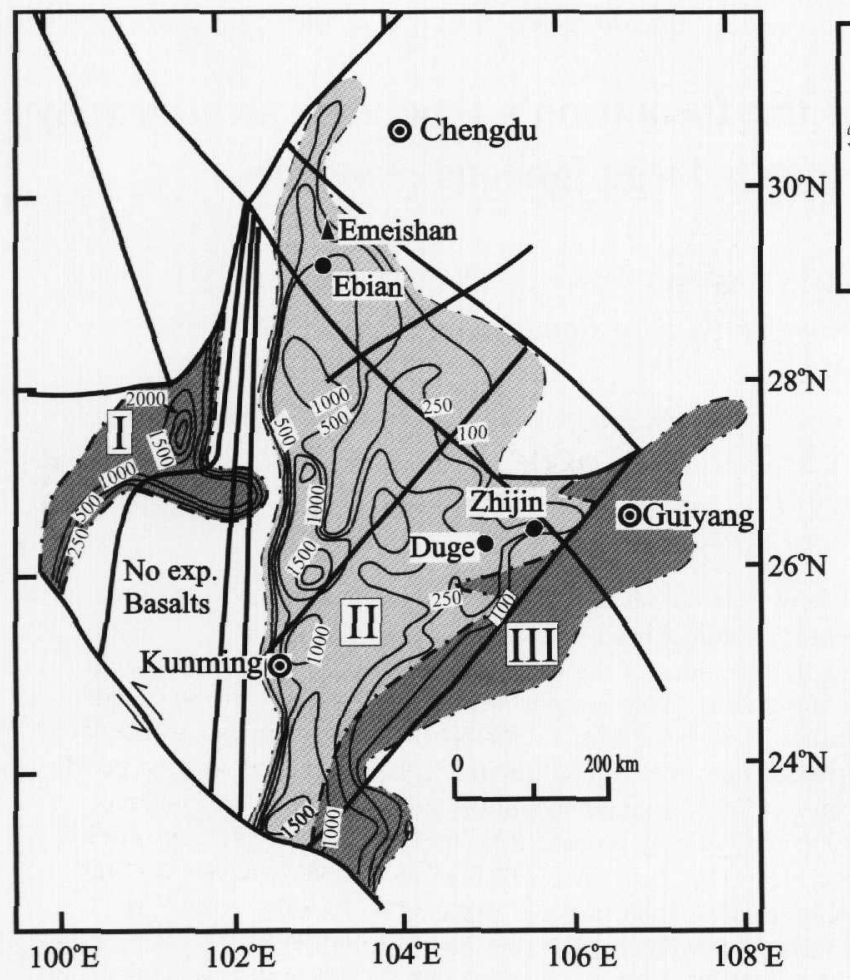

important insights, it has to be recognized that they were based primarily upon small geochemical datasets from a handful of outcrops in one part of the province. It is also worth drawing attention to the entirely rift-based (i.e. without plume) models proposed by Luo et al. (1990) and Dmitriev \& Bogatikov (1996) to explain the Emeishan Basalts' formation. The ideas behind the earlier paper were developed in the late 1970s-early 1980s and the first English version of the manuscript was submitted for publication before the various LIP generator models of 1989-1990 were published. Acknowledging a probable mantle plume involvement with the Emeishan Basalts, it remains appropriate that aspects of the rift-based models be considered in interpreting how the unit formed.

In the light of recent field observations in Sichuan Province (in the northern part of the terrain), we believe that the basic geology of the Emeishan Basalt Formation in and close to the type area is imperfectly understood. Therefore, the aim of this communication is to clarify the situation by outlining the stratigraphy of the unit and associated rocks there and to discuss the information in a LIP formation context. This in turn will provide the basis for future descriptions and interpretations of the terrain in areas away from the $\mathrm{Mt}$ (=shan) Emei stratotype area.

\section{Geological setting}

A map showing the Emeishan Basalt outcrop is presented in Figure 1 and a stratigraphic summary of the unit and associated rocks in those locations visited is shown in Figure 2. The Permian-Triassic geology of both the Mt Emei area and Ebian County consists of folded and faulted sequences of Lower Permian Maokou Formation sediments, Upper Permian Emeishan Basalts and uppermost Permian-Lower Triassic sediments. The Maokou Formation, which is a limestone unit. was deposited on top of a thick Palaeozoic sequence of the South China Block (e.g. Lee 1939; Yang 1986; Liu \& Xu 1994).
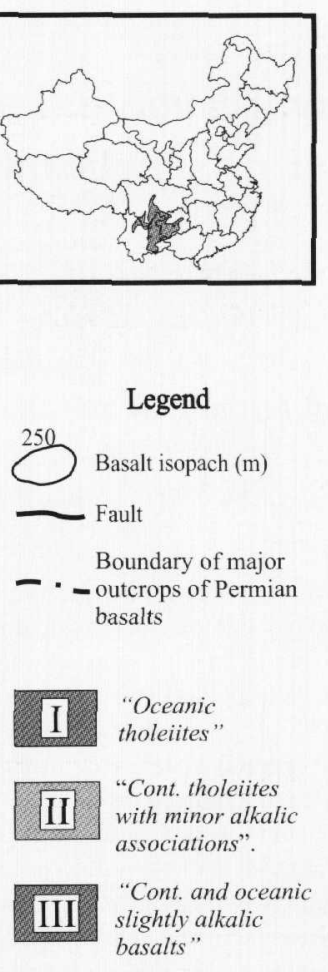

Fig. 1. Map showing the aerial extent of the Emeishan Basalts (based on Liu \& $\mathrm{Xu}$ 1994) and localities mentioned in the text.

Somewhat conveniently, the Cenozoic structural dismemberment of the region has raised individual blocks (kilometre to sub-kilometre scale) several hundred metres and subsequent erosion has produced a number of outcrops where substantial parts of the sequence can be inspected without gaps. In addition, just south of Xin Chung village, on the road leading to Ebian town, the entire Emeishan Basalt sequence can be seen in a massive inaccessible cliff face.

\section{Underlying sedimentary rocks: Maokou Formation}

In Ebian County, the conformable contact between the basalts and underlying sediments can best be observed in the road section to the north of Ebian town at $29^{\circ} 16.139^{\prime} \mathrm{N} /$ $103^{\circ} 16.392^{\prime} \mathrm{E}$ (Fig. 3). The sediments, which are several hundred metres thick, are assigned to the Maokou Formation, which is a limestone of Early Permian age (Lee 1939; Yang 1986; Anon 199la,b). The top $10-15 \mathrm{~m}$ of the formation comprises $0.05-0.2 \mathrm{~m}$ thick beds of blocky grey limestone with occasional thin layers rich in chert. The uppermost $0.5-0.8 \mathrm{~m}$ of sediments show clear alteration, presumably due to the sediment reacting to the hot lava as it was erupted onto a wet surface. In the Qing Yin power station section $\left(29^{\circ} 34.671^{\prime} \mathrm{N} /\right.$ $103^{\circ} 24.518^{\prime} \mathrm{E}$ ) near Mt Emei, the basalts rest conformably upon a $1.0-\mathrm{m}$ thick lignite, which in turn sits conformably on top of Makou Formation limestones. The sedimentary rocks formed in a shallow-marine-lagoonal environment (Anon $1991 a, b)$. Both these works show this is a regional feature of the Emeishan Basalt Fm and not just restricted to the Emei and Ebian region. With regard to the plume/non-plume argument, this information suggests locally at least that there was negligible uplift immediately prior to the eruption of the Emeishan Basalts. In addition, the lack of an unconformable surface within the upper Maokou Limestones and/or the absence of a facies change within the upper part of the unit 


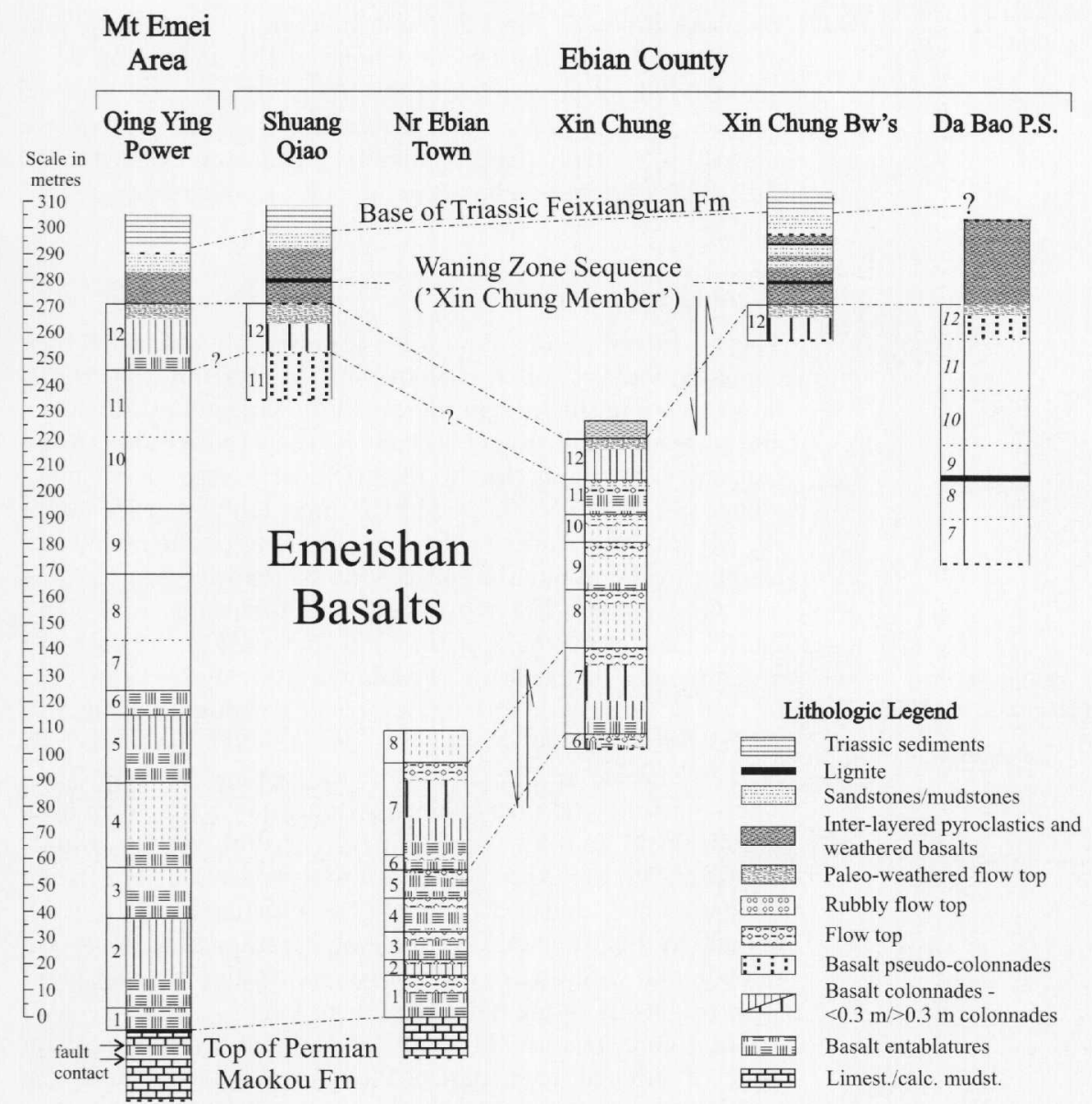

Fig. 2. Stratigraphic summary of the sections in Ebian County and the Mt Emei area. Where flows are too poorly exposed to determine their internal structure (colonnades etc) they are left blank. Dashed lines indicate that the contact between flows or units is obscured or questionable. While 12 flows are recognized at both Emei and Ebian, a flow-by-flow correlation is not inferred. In the Da Bao section, the flow numbers are italicized as they are inferred from their relationship with the waning zone and more complete sections at Emei, Xin Chung and Shuang Qiao. would seem to preclude an uplift phase 1-2 Ma prior to volcanism.

\section{Emeishan Basalts}

In Ebian county, the Emeishan Basalts and the overlying rocks can be physically inspected at three overlapping road sections just above and in $X$ in Chung village $\left(29^{\circ} 17.933^{\prime} \mathrm{N} /\right.$ $103^{\circ} 16.466^{\prime} \mathrm{E}$ ) and down towards Ebian town. in a river section just to the south of Shuang Qiao village $\left(29^{\circ} 20.145^{\prime} \mathrm{N} /\right.$ $103^{\circ} 17.594^{\prime} \mathrm{E}$ ), and at series of outcrops in the village of $\mathrm{Da}$ Bao $\left(29^{\circ} 06.404^{\prime} \mathrm{N} / 103^{\circ} 10.440^{\prime} \mathrm{E}\right)$, about $20 \mathrm{~km} \mathrm{SW}$ of Ebian. At the Qing Yin power station section, the lower half of the basalt sequence (six flows) is continuously exposed in a river course and adjacent road cuttings. The upper half of the basalts at Qing Yin are discontinuously exposed along the steep pathway adjacent to the power station water supply pipe and in a car park and nearby roads (within a $0.5 \mathrm{~km}$ or so) that lead to a Qing Yin Ge Temple.

In describing the Emeishan flows the terminology of Self et al. (1997) was adopted. Flows range in thickness from 6 to $35 \mathrm{~m}$ with typical values of $10-15 \mathrm{~m}$. The lower fifth/third of each flow has aphyric/feldspar-phyric textures and the contact with the underlying flow is always very sharp. The middle part of each flow is typically aphyric in which occasional zones of large amygdales occur. Cooling jointing within the flows form one or more well developed colonnades, pseudo-colonnades where columns are not well developed, and/or entablatures. The columns are perpendicular to the flow base and range in width from 0.2 to $0.5 \mathrm{~m}$. The upper third/quarter of each flow is characterized by abundant vesicles/amygdales and evidence to suggest gentle weathering prior to the eruption of the next flow. Critically, when viewed from a distance, the top of each flow appears dusty whilst the overlying younger flow forms a distinct overhanging ledge, thus units can easily be traced across the landscape. Multiple lobes, indicating a compound flow, were observed only in the thickest flow (7. c. $35 \mathrm{~m}$ at Xin Chung). All other flows appear to be simple lava flows or flow lobes. The similarity of the rocks to those documented in the Columbia River Flood Basalt Province (Self et al. 1997) suggests similar emplacement mechanisms. The only notable exception is the lack of flows (or flow fields) that are around $100 \mathrm{~m}$ thick. Other features we consider important are (1) the basalt pile is made up of only a small number of flows (12 at both Ebian and the Ebian-Xin Chung area); (2) the basalt pile in the two areas is $180-270 \mathrm{~m}$ thick, making it rather thin; (3) the lack of intensively weathered flow tops/absence of paleosols suggests a geologically short interval between flows.

\section{Palaeoweathered uppermost basalt flow}

In the field area, the uppermost Emeishan Basalt flow has been considered to have been overlain by fractured red/brown mudstones that pass upwards into a continental sedimentary sequence (e.g. Ma et al. 1993). This interpretation is incorrect: the 'mudstone' is infact the heavily (palaeo) altered top of the last proper Emeishan Basalt flow (Fig. 2). The presence of intact, albeit intensively weathered, volcanic-rock textures including amygdales, and the clear lack of evidence (bedding, 


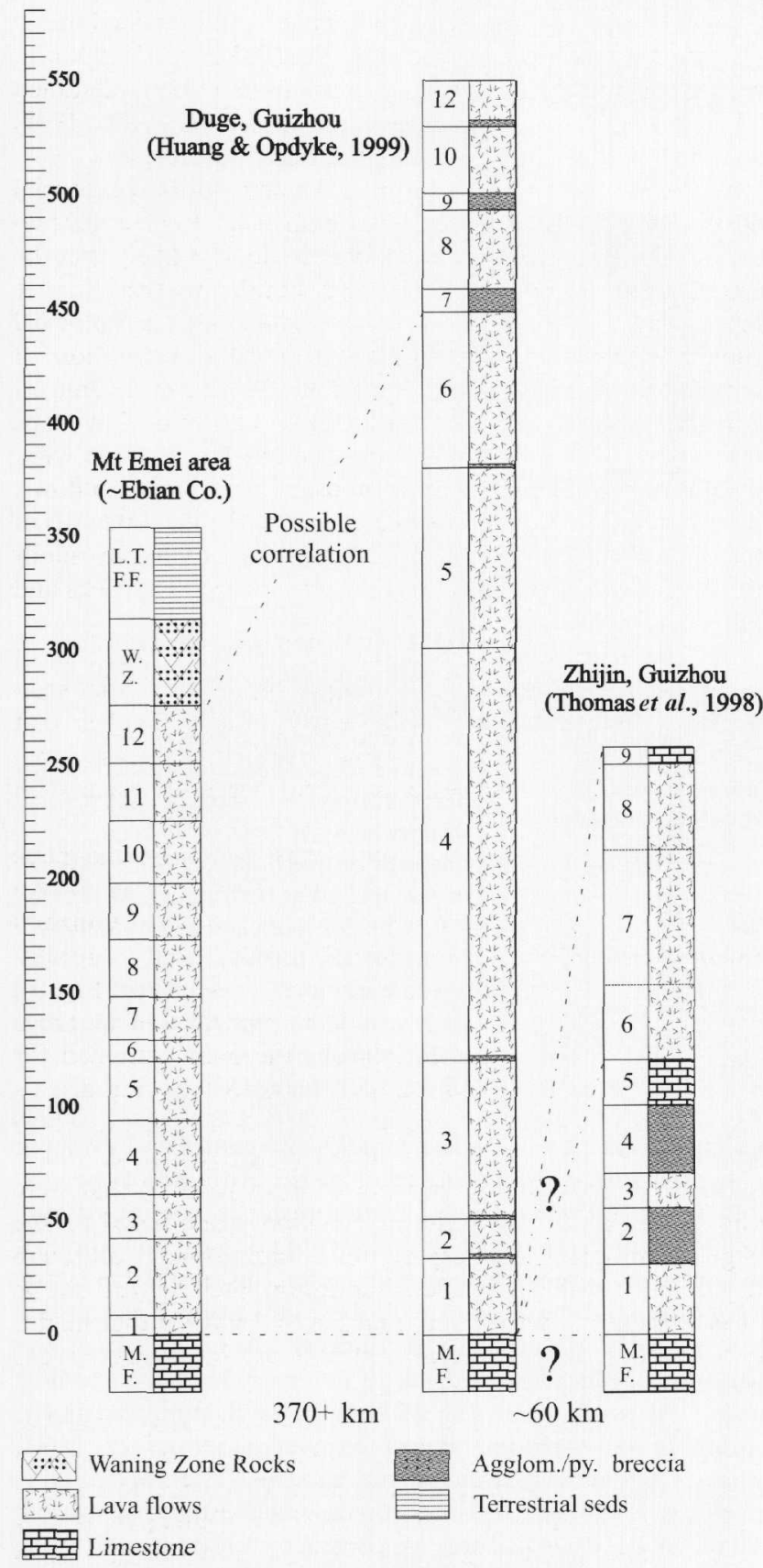

Fig. 3. Stratigraphic summary of the Emeishan Flood basalts in the type area and western Guizhou Province as reported by Huang \& Odyke (1998) on the section at Duge and Thomas et al. (1998) on the section at Zhijin.

sediment grains, and related textures) to indicate a depositional origin for these rocks provides the basis for this re-interpretation. The misidentification probably came about because the unit is often poorly exposed and forms topographic lows or water courses and/or is heavily vegetated (Shuang Qiao and Qing Yin). However, the unit can be seen clearly in three sections close to Xin Chung (at the village, the brickwork road cutting above the village and on the road leading to Ebian) and at Da Bao. At Qing Yin the same unit can be recognized in small bluffs where the canal feeds the power station water pipe, but it is very weathered. In interpreting this unit, we suggest that a prolonged period of sub-aerial exposure followed the last main Emcishan Basalt flow, and draw attention to the fact that none of the underlying flows and overlying rocks are weathered to the same degree. Because the unit can be traced over several tens of kilometres, we suggest it marks a sub-regionally significant event in the Emeishan Province as basalt production terminated.

\section{Waning zone sequence}

The weathered part of Flow 12 is conformably succeeded by a complex body of rocks, c. $30 \mathrm{~m}$ thick, comprising thin basalt flows (0.5-3 $\mathrm{m}$ thick); ignimbrites, tuffs, sandstones, siltstones and at least one lignite. This unit is best exposed along road cuts and excavations close to the brickworks above Xin Chung village $\left(29^{\circ} 34.866^{\prime} \mathrm{N} / 103^{\circ} 24.330^{\prime} \mathrm{E}\right)$. Importantly it crops out in the Mt Emei area near to the junction between the main road leading to the mountain and the minor road leading to Qing Yin Ge Temple. The pyroclastic and tuffaceous rocks and basalts, make up $>60^{\prime \prime} \%$ of the total thickness of the unit, the latter mainly in the form of yellow/white claystones in beds $0.5-1.0 \mathrm{~m}$ thick with varying degrees of welding. A distinctive ignimbrite, with felsic clasts $c .1-2 \mathrm{~cm}$ occurs in the lower part of the sequence at Xin Chung brickworks and Shuang Qiao. The sandstone and finer-grained sedimentary rocks form beds $1-2 \mathrm{~m}$ thick and are predominantly red/brown in colour. However, in the Xin Chung Brickwork section, a pristine laminated fine sandstone/siltstone has a distinctive dark green colour. In the lower third of the unit, a conspicuous $15-40 \mathrm{~cm}$ thick lignite with quartz grit matrix occurs and includes plant stem fragments, some more than $5 \mathrm{~cm}$ long.

The significance of this body of rocks and the underlying 'unit' (weathered upper part of Flow 12) is that they mark the terminal phase of Emeishan volcanism; in LIP-related discussions these rocks are a key element. As far as we can ascertain, none of the internationally published works on the Emeishan Basalt province have described correctly the important package of rocks sandwiched between the (Late Permian) basalts and the Triassic continental sediments. The most detailed description (by Ma et al. 1993, working in the Mt Emei area) assigned this interval to the Xuanwei Formation and summarized it as a Late Permian unit 'comprising purplish-red claystone interbedded with purplish-grey to dark red medium grained sandstone with thin coal seams', with no reference to the volcanic component. According to one author (X.S.), the unit has been described similarly in the Chinese literature. To avoid future confusion, and ensure that this unit is give the appropriate exposure in LIP discussions we suggest that it be re-labelled the Xin Chung Member of the Emeishan Basalt Formation.

\section{Overlying sediments}

Resting on the waning stage sequence are red brown claystones and sandstones of the Triassic Feixianguan Formation. We examined the lowermost $20-30 \mathrm{~m}$ of the unit in exposures near Xin Chung, Shuang Qiao and in the Mt Emei area for which the following observations are applicable. Some of the sandstone beds are $c .1 .5 \mathrm{~m}$ thick with some cross bedding and burrows. The claystones generally form beds $2-12 \mathrm{~cm}$ thick but there are units up to $1.5 \mathrm{~m}$. Occasional breccias occur in which the clasts are $c .1 \mathrm{~cm}$ in diameter and matrix supported. Cross-bedding, channel-fill structures, red colouration, carbonaceous material, desiccation cracks and raindrop pits 
indicate that these rocks were deposited in a terrestrial environment. While the basal conglomerate between the Triassic and Permian units was not found in situ, such conglomerates occur as large float boulders in the river at Shuang Qiao indicating an outcrop nearby. The conglomerate clasts, a few centimetres in diameter, include red/brown sandstones/ mudstones and weathered basalts. While the study was not exhaustive, nowhere did we observe large clasts from the Emeishan Basalts and overlying volcanic sedimentary package (or of the Permian Maokou Formation limestones). This suggests that extensive denudation of the underlying rocks did not occur.

\section{Palynological studies}

Wherever appropriate sedimentary rocks were found, samples (ten in total) were collected that were later examined for their palynological content (by D.W.J.). The aim of the study was (1) to determine independently the age of the Emeishan Basalts and (2) to deduce the environmental conditions at the time of their eruption. In terms of dating, the data are somewhat inconclusive because structured organic material (pollen and spores) are rare in most samples. Only one sample (from the Xin Chung Member at the Xin Chung Brickworks section) yielded an age diagnostic flora with poorly preserved Leiotriletes spp. (a fern spore) and some bisaccate coniferous pollen, similar to that attributed to Pinus weiyuanensis Zhang (1984). Other poorly preserved spores include a form similar to Orientalisporites sp. which was reported by Zhang (2000). There are also bryophyte type spores which are referable to Stereisporites (Distgranulisporis) spp., but which Zhang (2000) refers to as Sphagnum. A possible Cycadopites sp. type grain (cycad) is present also.

Unfortunately, the palynological material is insufficient for us to provide a precise age on the examined Emeishan Basalt sections. Therefore, until new data become available the pre-'mid- to late Upper Permian' age for the Emeishan Basalts implicit in Wang's (1983) study is the best estimate of the unit's age in the type area. Such information indicates that the eruption of the Emeishan Basalts could not have had a direct role in the Permian-Triassic boundary extinction, which is contrary to the conclusion of Chung et al. (1998).

With regard to the environmental condition, many of the examined samples contain a preponderance of ferns and lycopod types, indicative of a maritime climate.

\section{Summary of key direct observations}

(1) The first Emeishan Basalts were probably erupted near to sea level: volcanism appears not to have been preceded by substantial regional uplift as many of the mantle-plume models predict.

(2) The basalts rest on shelf limestones/lignites. There is no evidence to indicate large-scale rifting related to lithospheric thinning, otherwise the basalts might be expected to cap a distinctive rift sequence as, for example, Menzies et al. (1992) and Sheth (1999) have suggested.

(3) At $180-270 \mathrm{~m}$ thick, the main basalt flow pile is very thin compared to sections reported from other continental floodbasalt provinces/volcanic rifted margins (e.g., Siberia, Parana, east Greenland etc).

(4) The main basalt pile comprises a limited number of flows (12), which is unusually low for a complete section in a LIP, for example in Ethiopia, Rochette et al. (1998), identified
43 flows in a section; in Yemen 110 have been identified in the $>1.1 \mathrm{~km}$ thick section at Wadi Lahima (Baker et al. 1996); in west Greenland, Riisager \& Abrahamsen (1999) identified 289 flows in a composite sequence; in India, West (1999) identified 48 flows in a Deccan Trap borehole section.

(5) During the mid-late Permian the area was at equatorial location, not far from the sea, e.g. Enkin et al. (1992) and Zhao et al. (1996), and probably at a low altitude. It is likely that the climate there was hot and humid and that the weathering rates were high (this assumption is supported by our palynological studies in which maritime-indicative lowland vegetation of ferns and lycopod types are dominant). We therefore suggest that the lack of palaeosols/intensely weathered flow tops indicates that the flows were erupted in quick succession with, say, no more than a few tens of thousand years between flows.

(6) The termination of volcanism was marked by intervals of weathering and terrestrial sedimentation punctuated by minor effusive activity in the form of thin lavas, pyroclastic rocks and ash fall deposits.

(7) The terrain was not denuded following the end of volcanism and the transition to uninterrupted terrestrial sedimentation in the latest Permian--early Triassic implies that deposition took place close to the local/regional base level. This suggests that local/regional subsidence took place soon after volcanism ceased.

In addition to our own observations, the palaeomagnetic studies of Huang \& Opdyke (1998) and Thomas et al. (1998) on two Emeishan Basalt sequences in western Guizhou Province, around $400 \mathrm{~km}$ to the SE, provide useful information with which to compare the Sichuan sections (see Fig. 3). The section Huang \& Opdyke (1998) reported on at Duge $\left(26.4^{\circ} \mathrm{N} / 104.7^{\circ} \mathrm{E}\right)$ shows similarities to the ones examined for this study. From their figure 2 and the accompanying discussion, the basalt pile they encountered is $550 \mathrm{~m}$ thick, which again is thin for a continental flood basalt sequence, and is made up of similarly low number of flows (twelve) that were erupted quickly (of the order of 1 million years, based on the magnetostratigraphic interpretation). Interestingly, although they do not provide a detailed description, their figure 2 shows a basalt section topped by a sequence (units 7-12) that might, in its broadest sense, correlate with the waning interval rocks of the Xin Chung Member.

In contrast, the section that Thomas et al. (1998) studied at Zhijin $\left(26.5^{\circ} \mathrm{N} / 105.7^{\circ} \mathrm{E}\right)$ is quite different to both the sections in Sichuan and the more proximal one in Guizhou. The $260 \mathrm{~m}$ thick volcanic sequence formed in two distinctive phases separated by a significant period of limestone deposition when $20 \mathrm{~m}$ of sediment accumulated. As Thomas et al. (1998) pointed out, the presence of a substantial shelf limestone package within the middle of the succession requires, locally at least, for subsidence of the sub-aerially erupted lava pile to several tens of metres or more below sea level followed by uplift when the second phase of volcanic activity took place. The first volcanic episode comprises two proper flows that are both overlain by volcanic breccia. The differences in magnetization directions, presumably reflecting geomagnetic secular variation, between the successive units (see their table 2) suggests four events separated in time. The second phase of volcanism spans $130 \mathrm{~m}$ of section and is in the form of three flows. Clearly the quite different stratigraphies in the two Guizhou sections indicate that terrain-wide correlations should be exercised with caution.

From Figure 1, it can be seen that the northern and eastern flanks of the Emeishan Basalt Formation are marked by 
sequences $100-250 \mathrm{~m}$ thick. To the south and west of the type area the basalt pile becomes expanded with localized highs in excess of $1 \mathrm{~km}$; according to a Y. Xu (Pers. comm. 2000) there exists in the western part of the terrain sections c. $5 \mathrm{~km}$ thick. Having not visited these areas, any interpretation as to the variable local thickening is somewhat speculative. One explanation is that the highs represent volcanic centres, possibly related to leaky rift faults. Alternatively, the pile may have been locally thrust-stacked due to India's continued indentation into Eurasia following their initial collision in the Paleogene. Unfortunately, not enough detailed published information is available to enable comparisons to be made with the sections in the Emeishan Basalt type area/Guizhou Province.

\section{Emeishan Basalts: an LIP in a failed rift setting?}

Several factors suggest that the Emeishan Basalts represent a LIP although volcanism due to rifting and/or plume impaction may have been prematurely terminated. Although the estimated erupted volume is comparatively small, at about a $0.25 \times 10^{6} \mathrm{~km}^{3}$ it remains an impressive massif. The work of Huang \& Opdyke (1998), implying rapid emplacement, and the geochemical studies of Chung \& Jahn (1995) and Chung et al. (1998) requiring a mantle plume involvement, suggest a links to processes commonly associated with LIP generation. However, the continental rift basalt province did not evolve into a volcanic rifted margin. An explanation as to why this happened is possibly provided by the East Asia mid-Permianearly Triassic plate models. At that time, eastern Tethys looked not dissimilar to present-day offshore SE Asia and a whole series of blocks (almost all derived from eastern Gondawana) were closing down Palaeo-Tethys and accreting onto eastern Eurasia (Scotese \& Langford 1995). The South China Block, to which the Emeishan Basalts were emplaced at its western end, was at that time colliding with the North China Block (the two blocks were also moving northwards). The collision started in the mid-late Permian and involved the scissor-like closure of the intervening Songpan Sea about pivot point in the east (Enkin et al. 1992; Zhao et al. 1996). As the South China Block rotated clockwise towards the North China Block, the Songpan Sea slowly closed shutting down in the Late Jurassic. Throughout this interval the Indo-China, Sibumasu and Cimmerian mini-continents lay just to the south/west of South China and were slowly amalgamating with that block (e.g. Metcalfe 1996, fig. 13; Wang et al. 2000, fig. 10). Thus if a rising mantle plume impacted beneath the western South China Block, the effect of several continental fragments converging about a broadly similar point may have stalled the rifting (by constriction) and thereby terminated decompression related volcanism (in part the idea that was suggested by Dmitriev \& Bogatikov 1996).

A second explanation could be that the relatively rapid northward motion of the South China Block moved the Emeishan area off the mantle-plume head before decompression volcanism, induced by break-up following rifting, had the chance to get started. Evidence for a failed rift, to the west of the Emei area, can be deduced from the 1:1000000 map series encompassing Sichaun, Yunnan and Guizhou Provinces, that is, the absence of true oceanic crust to the west of the South China Platform and the absence of deep-marine sediments onlapping the Emeishan Basalts (and no remnants for an ocean island trail preserved in the South China/Indochina suture as is the case for the Chagos-Laccadive Ridge, which links the Reunion Hotspot and the Decan Traps).

\section{Conclusions}

Using field observations of the Emeishan Basalt Formation of SW China we have described the basic stratigraphy of the sequence close to its type area and clarified the interpretation of important units. The Emeishan Basalts appear to mark the site of a Late Permian LIP in which volcanic activity was of a limited scale, relatively short-lived, and occurred some time before the Permian-Triassic boundary. The system appears to have terminated abruptly, that is, the rifting did not lead to the development of a volcanic rifted margin. Alongside the Siberian Traps (another rift system which lacks a related ocean basin), the province might provide a useful end-member in LIP modelling studies. In future, through a combination of detailed field observations elsewhere in the terrain and a programme of dating and geochemical studies, we hope to evaluate this basic model. Although the Emeishan Basalt geochemical studies of Chung \& Jahn (1995) and Chung et al. (1998) suggest a mantle-plume involvement, aspects of the rift-based (without plume) models of Luo et al. (1990) and Dmitriev \& Bogatikov (1996) should be considered in such discussions.

This research was funded by a Stephen S.F. Hui Fund grant to G.T and a HKU CRCG grant to J.R.A. Martin Menzies and Andy Saunders are thanked for their constructive reviews.

\section{References}

Anderson, D.L., Zhanc, Y.S. \& Tanimoto. T. 1992. Plume heads, continental lithosphere, flood basalts and tomography. In: Storey. B.C.. Alabaster, T. \& PANkhurst. R.J. (eds) Magmatism and the Catses of Continental Break-up. Geological Society, London. Special Publications, 68, 99-124.

Anon. 1991a. [Regional Geology of Sichuan Province]. Geological Memoir Series. 23. Geologic Press. Beijing. [in Chinese].

Anon. 199lb. [Regional Geology of Kuman Prowince). Geology Memoir Series. 23. Geologic Press, Beijing. [in Chinese].

Baker. J.. Snee, L. \& Menzies. M. 1996. A brief Oligocene period of flood volcanism in Yemen: implications for the duration and rate of continental flood volcanism at the Afro-Arabian triple junction. Earh and Planetary Science Letters, 138, 39-56.

Campbell, I.H. \& Griffitis. R.W. 1990. Implications of mantle plume structure for the evolution of flood basalts. Earth and Planetary Science Lathers. 99. 79-93.

Chung, S.L. \& JAHN, B.M. 1995. Plume-lithosphere interaction in generation of the Emeishan flood basalts at the Permian-Triassic boundary. Goologir 23. $889-892$.

Chung. S.L.. JahN, B.M. WU. G.Y.. Lo. C.H. \& Cong, B. 1998. The Emeishan flood basalt in SW China: a mantle plume initiation model and its connection with continental breakup and mass extinction at the PermianTriassic boundary. In: Flower. M.F.J.. Chung, S.L., Lo, C.H. \& LeE. T.L. (eds) Mantle dynanics and plate interactions in East Asia. AGL Geodynamics Series, 27, 47-58.

Courtillot, V., Jaupart, C.. Manighetti, I., Tapponnier, P. \& Besse, J. 1999. On causal links between flood basalts and continental breakup. Earlh Planetary Science Letters, 166, $177 \cdot 195$.

Dmitriev, Y.I. \& Bogatikov, O.A. 1996. Emeishan flood basalts. Yangtze Platform: indicators of an aborted oceanic environment. Petrology, 4. $407-418$.

Enkin, R.J., Yang, Z., Cilen, Y. \& Colrtili.ot, V. 1992. Paleomagnetic constraints on the geodynamic history of the major blocks of China from the Permian to the present. Joumal of Geophysical Research. 97. 1395313989.

HUANG, K. \& OPDYKE. N.D. 1998. Magnetostratigraphic investigations of an Emeishan basalt section in western Guizhou Province, China. Earth and Planetary Science Luters, 163,1-14.

Jiv, Y.G., Wang. Y.. Wang. W., Shang. Q.H.. CaO, C.Q. \& ERWin, D.H. 2000. Pattern of marine mass extinction near the Permian-Triassic boundary in south China. Science, 289. 432-436. 
KeEn, C.E. \& Boutilier, R.R. 2000. Interaction of rifting and hot horizontal plume sheets at volcanic margins. Journal of Geophysical Research. 105, $13375-13387$.

Kent. R.W., Storey. M. \& Saunders, A.D. 1992. Large igneous provinces: sites of plume impact or plume incubation? Geology, 20, 891-894.

KING, S.D. \& ANDERson, D.L. 1995. An alternative mechanism of flood basalt formation. Earth Planetary Sitence Letiers, 136, 269-279.

LEE. J.S. 1939. The Geology of China. Thomas Murby \& Co, London.

LIL, B. \& XL. X. (eds) 1994. Allas of the lithofacies and paleogeography of South China (Sinian-Triassic, Science Press. Beijing.

Luo. Z.. JIN, Y. \& ZhaO, X. 1990. The Emei taphrogenesis of the upper Yangtze Platform in south China. Geological Magazine, 127, 393405

MA, X., MCElhinvy, M.W., Embleton, B.J.J. \& Zhang, Z. 1993. Permo-Triassic paleomagnetism in the Emei Mountain Region, southwest China. Geophysical Journal International, 114, 293-303.

MaHoney, J.J. \& CoffIn, M.F. (eds) 1997. Large izneous provinces: continental oceanic and planetary flood volanism. AGU Geophysics Monographs, 100.

Menzies, M.A., Baker, J., Bosence, D., Dart, C., Davison, I., Hurford, A. Al 'Kadasi, A. McClay. K. Nichols. G.J., Al'Subrary, A. \& Yelland. A. 1992. The timing of magmatism, uplift and crustal extension: preliminary observations from Yemen. In: Storey, B.C., Alabaster. T. \& Pankhurst. T.J. (eds) Magmatism and the Causes of Continental Break-up. Geological Society, London. Special Publications, 68, 293-304.

Menzies, M.A., Ebivger, C. \& Kiemperer. S. 2000. Penrose Conference Report: Volcanic rifted margins. GSA Today, 10(8), 8-11.

Metcalfe, I. 1996. Pre-Cretaceous evolution of SE Asian terranes. In: Hall, R. \& BLLNDELL, D.J. (eds) Tectonic evolution of SE Asia. Geological Society, London. Special Publications, 106, 97-122.

Mutter, J C., Buck. W.R. \& Zehnder. C.M. 1988. Convective partial melting I. A model for the formation of thick basaltic sequences during the initiation of spreading. Jounal of Geophysical Research, 93, 10311048.

Richards. M.A.. DLNCAN, R.A. \& Colr ILlot, V.E. 1989. Flood basalts and hotspot tracks: plume heads and tails. Science. 246, 103107

RiISAgFr, P. \& ABrahamsex, N. 1999. Magnetostratigraphy of Palaeocene basalts from the Vaigat Formation of West Greenland. Geoplysical Journal International, 137, 774-782.

Rochette, P. Tamrat, E. Ferald, G., Pik, R. Courtillot, V., Ketefo, E., Coulon, C., Hoffmani, C. Vandammme. D. \& Yirgu, G. 1998. Magnetostratigraphy and timing of the Oligocene Ethiopian Traps. Earth and Planetary Science Letters, 164, 497-510.

SCOTESE, C. \& LANGFoRd. R.P. 1995. Pangea and the paleogeography of the Permian. I $m$ : Scholle. P.A., Peryt, M. \& Ulmer-Scholle, D.S. (eds) The Permian of northern Pangea. Springer-Verlag. $3 \cdots 19$.
Sel., S., Thordarson, T. \& KeszThelyi, L. 1997. Emplacement of continental flood basalt lava flows. In: MAHONEy, J.T. \& COFFin. M.F. (eds) Large Igneous Provinces: Continental, Oceanic and Planetary Flood Voleanism. American Geophysical Lnion. Geophysical Monographs. 100, 381-410.

SHETH, H.C. 1999. A historical approach to continental flood basalt volcanism: insights into pre-voleanic rifting, sedimentation, and early alkaline magmatism. Earth and Planetary Science Letters, 168, 19-26.

Storey, B.C. Alabaster, T. \& Pankhurst, R.J. (eds) 1992. Magmatism and the Causes of Continental Brtak-up. Geological Society, London. Special Publications. 68.

Thomas, D.N., Rol ph. T.C. Shaw, J., Gonzalez de Sherwood, S. \& Zhuang, Z. 1998. Palaeointensity studies of a late Permian lava succession from Guizhou Province, South China: implications for post-Kiaman dipole field behaviour. Geophysical Journal International. 134, 856866.

WAvG, H. 1983. Fossil plants from the upper Permian Shawan Formation in Longmendong, Emei, Sichuan Province. Joumal of Chengdu College of Geology, 10.91.99.

Wang, X., Metcalfe, I.. Jian, P., He. L. \& Wang, C. 2000. The Jinshajiang. Ailoshan Suture Zone, China: tectonostratigraphy, age and evolution. Journal of Asian Earth Sciences. 18, 675-690.

Wang, Y., Li. J., Zhol, R., Wang. W., Tong. C. \& Xiong. S. 1987. Principle on trace element geochemistry of igneous rocks and its applications and demonstration of the petrogenesis of the Emeishan basalts]. Chengdu Science and Technology Publishing House, Chengdu, China, [in Chinese].

White, R \& MCKEvzie, D. 1989 . Magmatism at rift zones: the generation of volcanic continental margins and flood basalts. Journal of Geophysical Research, 94, 7685-7729.

WEST, W.D. 1999. The petrography and petrogenesis of forty-eight flows of the Deccan Traps penetrated by borings in western India $\mathrm{In}$ : Menoirs of the Geological Society: India, 43, 641-704

Yang, Z.Y. 1986. The Permian system. In: Yang. Z.Y., Cheng. Y.Q. \& Wang. H.Z. (eds) The Geology of China. Clarendon Press, Oxford, 113125.

ZHANG, L. 1984. Late Triassic spores and pollen from central Sichuan. Palaeontologica Sinica, 167A(8), 1-100.

ZIIANG, L. 2000. Upper Triassic palynoflora from northeast Guizhou, China. In: SoNG, Z. (ed.) Palynoftoras and pallnomorphs of China. Press of University of Science and Technology of China. 41.52.

Zhao, X., Coe, R.S., Gilder, S.A. \& Frost. G.M. 1996. Palcomagnetic constraints on the paleogeography of China: implications for Gondwanaland. Australian Journal of Earth Sciences, 43, 643-672. 